\author{
Sarah Stafford \\ College of William and Mary
}

College of William and Mary

Department of Economics

Working Paper Number 77

Current Version: May 2010

Previous Version: September 2008 
COLLEGE OF WILLIAM AND MARY

DEPARTMENT OF ECONOMICS

WORKING PAPER \# 77

May 2010

\title{
How Green is Your Campus? An Analysis of the Factors that Drive Universities to Embrace Sustainability
}

\begin{abstract}
I examine the factors that influence the adoption of sustainable practices by institutions of higher education (IHEs) in the U.S. Using data from the Sustainable Endowments Institute, I conduct an ordered probit analysis on 180 IHEs. The results show that size and wealth are significant factors in the adoption of sustainable practices and that stakeholders such as faculty, alumni, and the surrounding community also play an important role. I find no evidence that institutions adopt sustainability to attract students. Also, in contrast to the findings of similar studies on for-profit entities, there is no evidence that regulatory pressures encourage campus sustainability. I also examine the factors that affect the institutions' decision to sign the Presidents Climate Commitment (PCC), a largely symbolic gesture. The results for the PCC are quite different than those for overall sustainability. Most importantly, neither wealth or size are significant factors in that decision.
\end{abstract}

JEL Codes: Q01, L30, I23

Keywords: Sustainability, Higher Education, Regulatory Pressures, Stakeholder Influences, Voluntary Practices

Sarah Stafford

Department of Economics

College of William and Mary

Williamsburg, VA 23187-8795

slstaf@wm.edu 


\section{How Green is Your Campus? An Analysis of the Factors that Drive Universities to Embrace Sustainability}

\section{Introduction}

Much has been written on corporate sustainability and the factors that affect it, both in the academic literature and in the popular media. The literature on sustainability efforts at institutions of higher education (IHEs) is much smaller although colleges and universities can also pose significant environmental liabilities. Like many corporations, IHEs consume large quantities of energy and water. ${ }^{1}$ In addition IHEs generate significant volumes of solid wastes, including toxic and hazardous wastes. ${ }^{2}$ Also like corporations, IHEs currently face significant pressure to adopt sustainable practices. However, while corporations and IHEs face some similar challenges in deciding whether to adopt sustainable practices, there are many reasons why sustainability efforts on campuses may depend on different factors than corporate sustainability efforts. Obviously, the non-profit nature of most IHEs suggests that campus leaders can make investments in sustainable practices that corporations would not find profitable. Additionally, the types of stakeholders that have an interest in sustainability efforts varies significantly across IHEs and corporations. While companies may be pressured to adopt sustainable practices by consumers and investors, IHEs must respond to the concerns of students, faculty and alumni.

The goal of this paper is to examine campus sustainability efforts to determine the factors that drive IHEs to adopt sustainable practices. Given that recent congressional education bills have included provisions for the establishment of sustainability programs in the Department of Education, we are likely to see increased government efforts to promote sustainable practices on

\footnotetext{
${ }^{1}$ For example, Connecticut College consumed 120MMBtus of energy per student in 2004 (Cabaniss, 2006), while Yale University used 6 million gallons of water across campus in 2004 (Yale, 2005).

${ }^{2}$ The University of Georgia, for example, is responsible for a \$1.6 to \$2.6 million cleanup of hazardous and toxic waste at a former waste disposal site on campus (http://www.epa.gov/Region2/p2/college/protect.htm).
} 
campuses in the future. ${ }^{3}$ A more complete understanding of the factors that drive campus sustainability will be essential for crafting effective policy on this issue. This knowledge should also help increase the effectiveness of private groups that are trying to promote campus sustainability.

The analysis uses the same general framework that has been used to study corporate adoption of sustainable practices to highlight similarities and differences between the factors that affect corporate and campus behavior. Thus in addition to helping design programs to promote sustainability at IHEs, this study will also provide insight into the differences in environmental decision making at non-profit and for-profit entities more generally.

In the next section, I present a brief summary of the related literature and outline a conceptual framework for my analysis. The following section discusses the analytical approach in detail, describing both the data and the econometric model used in the analysis. I then present the results of the analysis and discuss the policy implications of my findings before concluding.

\section{Related Literature and the Conceptual Framework for the Analysis}

The majority of the literature on campus sustainability is directed towards people who want to increase sustainable practices on particular campuses or at institutions of higher education in general. ${ }^{4}$ The general focus of these papers is on why sustainability is important or how it can be implemented at IHEs. This literature includes many case studies of successful sustainability programs. Additionally, there are a few studies that take a more aggregate approach to understanding the factors that influence the success of sustainability initiatives. For

\footnotetext{
${ }^{3}$ See, for example, H.R. 4137, the College Opportunity and Affordability Act, passed on February 8, 2008. ${ }^{4}$ While there has not been a recent formal review of the literature on campus sustainability, AASHE maintains a list of publications on campus sustainability on its website (http://www.aashe.org/resources/publications.php, last accessed May 26, 2009).
} 
example, based on seven years of experience in implementing sustainable practices at IHEs Sharp (2002) identifies a number of approaches to sustainability that have proved to be most successful including management support, effective communication, partnerships with students, and continuity. Looking at the issue from the opposite point of view, Velazquez, Munguia and Sanchez (2005) identify barriers to implementing sustainable practices on campus. The authors find that the factors that are most frequently cited as impeding campus sustainability initiatives are a lack of awareness and interest in sustainability, the organizational structure of the institution, lack of funding, and lack of support from administrators.

This paper takes a very different approach. Instead of looking at particular examples of successful practices to determine what factors have contributed to the success of sustainability initiatives, I look more broadly at the general characteristics of IHEs to determine what underlying factors may be driving campuses to adopt sustainable practices. Thus this study is more closely related to empirical studies on sustainable practices in the corporate world than it is to the literature on sustainability in higher education.

\subsection{Empirical Findings on Corporate Sustainability}

While there is no one widely accepted definition of corporate sustainability, the term is generally used to describe practices that reduce a company's environmental impact and promote improvements in environmental quality. Additionally, for most people sustainability requires companies to go beyond mere compliance with current environmental regulations. Thus the literature on corporate sustainability focuses primarily on corporate adoption of voluntary environmental initiatives.

For example, Khanna and Anton (2002) analyze the factors that affect whether firms adopt environmental management systems (EMS). Adopting an EMS is a voluntary step that 
firms can take to improve their environmental performance both in terms of achieving compliance with environmental regulation and moving beyond regulatory requirements. Khanna and Anton find that firms that face a stronger threat of environmental liabilities and firms that face more stringent environmental regulation are more likely to adopt EMSs. The authors also find that firms in closer contact with their customers and firms that are more exposed to adverse stockholder and community reactions are more likely to adopt EMSs. Finally, the authors find that more innovative firms (as measured by R\&D expenditures) are more likely to adopt EMS, but they only find weak evidence to support the theory that market competition affects adoption.

In a similar study, Potoski and Prakash (2005) examine the characteristics of facilities that become ISO 14001 certified, a process that requires facilities to adopt a number of practices that should increase environmental performance. The authors find that facilities with higher levels of environmental exposure (i.e., higher levels of pollution) are more likely to join ISO14001 as are facilities facing more stringent environmental regulations. The authors also find that larger facilities are more likely to join as are facilities located in highly educated communities. The finding that community characteristics affect environmental performance is echoed in a paper by Gunningham, Kagan, and Thorton (2004). In this analysis, the authors examine the extent to which "social license" determines the environmental performance of forprofit firms. They define social license as the demands on and expectations for businesses that emerge from "neighborhoods, environmental groups, community members, and other elements of the surrounding civil society" and suggest it may drive for-profit firms to go beyond the level of environmental performance required by environmental regulations.

The three papers described above demonstrate the range of results that have been found in the empirical literature on corporate sustainability. (Readers who are interested in a more 
comprehensive review of this literature should refer to Khanna and Brouhle (2008) for a general survey.) While the results of the empirical analyses vary across programs and the universes being analyzed, as a whole these studies show that corporate adoption of sustainable practices depends on many different factors, including a company's potential liability from environmental damage (based on size and level of pollution), the stringency of environmental regulations, the likelihood of fines for environmental violations, the environmental preferences of consumers, and the environmental concerns of the community.

\subsection{Conceptual Framework for the Analysis}

For-profit firms and IHEs have very different objectives. By definition, for-profit firms seek to maximize profits. In contrast, IHEs have multiple goals such as providing high quality education to students, promoting research in numerous disciplines, and enhancing the general welfare of their community. The standard economic approach to modeling the objective function of the IHE is to create a value function that translates the outputs of a university - teaching, research, and service - into some ultimate measure of value that the IHE seeks to maximize (see, for example, Hopkins and Massey (1981)). It is clear that institutions care about both the quality and quantity of each output, although the relative weight of each output and the importance of quality relative to quantity in the value function is likely to differ significantly across IHEs. The specification of a particular institution's value function will depend on the underlying preferences of many individuals including the institution's governing board, its administration, alumni and donors, faculty, and students. As Clotfelter (1996, p. 23) explains “a university simply is many things to many people." Additionally, the outputs of a university are generally hard to measure both in terms of quantity and quality. Therefore, to provide a conceptual 
framework for the empirical analysis I use the following reduced-form model which is a simplified version of the model offered in Martin (2005).

Let $\mathrm{V}(\mathrm{Y})$ be the institution's value function, where $\mathrm{Y}$ is a vector containing the outputs of the university - teaching, research and service. Since these outputs are produced jointly, the joint production function can be represented as $Y=F(X)$ where $X$ represents the vector of inputs. The inputs include students, faculty, staff, buildings, libraries, etc. The IHE must maximize its value function subject to its production function and its budget constraint, that is $\mathrm{R}(\mathrm{Y}, \mathrm{X})-\mathrm{C}(\mathrm{X})$ $>0$ where $\mathrm{R}(\cdot)$ is the institution's revenue function and $\mathrm{C}(\cdot)$ is the institution's cost function.

Some outputs contribute directly to revenues because they command a market price. For example, the more students that an IHE educates, the greater its tuition revenue. Some research or public service may also directly increase revenue if it is conducted under a grant or contract. However, much research and service will have at best an indirect effect on revenues. Teaching (both in terms of quantity and quality) will also have an indirect effect on revenues because it will affect the number and generosity of alumni and other donors, as well as the willingness of students (and their parents) to pay for that teaching.

As is true for for-profit firms, market competition will affect the level of revenue the IHE will receive for its output. IHEs can increase their level of competitiveness by increasing the quality of their output or by offering additional inducements to the consumers of their outputs. For example, students may be willing to pay a higher tuition if the campus is environmentally sustainable. Alumni may be more willing to donate to an institution that adopts a needs-blind admission policy. Thus, the revenue function can also depend on the inputs to the production process. The last piece of the model is the cost function. The cost function of an IHEs is not necessarily different from that of a for-profit firm, although it may be slightly more complex than 
a standard cost function given that Cohn, Rhine, and Santos (1989) find that the cost function of IHEs generally exhibit both economies of scale and economies of scope.

In contrast to the value-maximizing IHE, a for-profit firm would maximize its profits $\pi=$ $\mathrm{R}(\mathrm{Y}, \mathrm{X})-\mathrm{C}(\mathrm{X})$ subject to its production function $\mathrm{Y}=\mathrm{F}(\mathrm{X})$. Despite the significant difference in objective functions, adoption of sustainable practices will have some of the same impacts on IHEs and for-profit firms. For both IHEs and for-profit firms, implementation of sustainable practices is likely to increase costs in many areas, at least in the short-run. For example, switching to renewable energy sources over traditional energy sources is likely to increase energy costs while building LEED-certified buildings can lead to higher design and construction costs. ${ }^{5}$ On the other hand, costs could decrease for both IHEs and for-profit firms if implementing sustainability decreases future operating or regulatory costs. Another similarity is that for both firms and IHEs, sustainable practices can increase revenues: for-profit firms may be able to charge a higher price for their product or receive cheaper capital from investors while IHEs may be able to increase tuition or receive more donations if they are environmentally conscious.

Despite the many similarities, there are also likely to be significant differences. One primary difference is that sustainable practices can increase an institution's value function directly because sustainable practices are part of the institution's contribution to the public. Additionally, to the extent that students and faculty care about the environment, sustainable practices may help an institution to attract higher quality students and faculty, thus increasing the quality of an institution's teaching and research. Another important difference is that in a dynamic setting, IHEs are likely to have a smaller discount factor, that is to weigh future gains

\footnotetext{
${ }^{5}$ LEED stands for Leadership in Energy and Environmental Design. LEED-certification is issued by the U.S. Green Building Council.
} 
more heavily, than a for-profit firm would. As Creighton (1998) points out, "the fact that most institutions of higher learning plan to exist well into the next century makes long-term thinking and investment...prudent." Additionally, unlike many executives of for-profit firms, university administrators are less likely to have the same financial incentives to focus on short-term, as opposed to long-term performance, if for no other reason that it is much more difficult to judge a university's "performance" in the short-run. Thus IHEs may be more likely to invest in sustainable practices that have a long-term impact than for-profit firms.

In summary, while many of the same basic factors should affect the adoption of sustainable practices at both for-profit firms and IHEs, it is likely the relative importance of the factors will differ significantly. For example, while environmental regulations and fines for environmental violations apply equally to IHEs and corporations, I would argue that the reputational effects of an environmental violation could be more significant for a university than it would be for an industrial plant because the public is likely to hold universities to higher standards than they would a plant. Similarly, one could argue that "social license pressures" will be more intense for IHEs than for corporations as many stakeholders will have higher demands or expectations for IHEs, particularly public institutions.

I also anticipate that students could have more influence on the adoption of sustainable practices at IHEs than consumers have on for-profit firms because of the continuous, long-term nature of the relationship between the student and the institution - a relationship that often extends well beyond the student's four years on campus. Also, students may have stronger preferences for the environment than the average customer of a corporate entity. I also think that overall IHEs are likely to be less influenced by financial considerations than for-profit firms both because they may be able to take a longer term view than for-profit firms and because IHEs may 
have a mission that includes service to the community. Encouraging sustainability and leading by example may be one way in which an institution achieves this mission.

\section{Analytic Approach}

To conduct this analysis, it is necessary to find a way to measure the extent to which IHEs have adopted sustainability. For the last several years the Sustainable Endowments Institute (SEI), a non-profit group "engaged in research and education to advance sustainability in campus operations and endowment practices," has evaluated the implementation of sustainable practices on campuses in North America. In particular, the SEI produces a College Sustainability Report Card covering the IHEs with the largest endowments in the U.S. and Canada. $^{6}$ SEI uses a combination of publicly available data (e.g., the institution's website, media coverage, data from EPA and the United States Green Building Council) and campus responses to a survey administered by SEI to evaluate campus sustainability. For this analysis, I used the 2008 report card (issued in 2007) which graded IHEs in eight categories: Administration, Climate Change and Energy, Food and Recycling, Green Building, Transportation, Endowment Transparency, Investment Priority, and Shareholder Engagement. For each of these categories of sustainable practices, institutions earn points based on their policies for the "indicators" selected by SEI for that category. For example, in the Climate Change and Energy Category there are six indicators: whether there is a carbon emissions inventory, the type of commitment the IHE has made toward emissions reduction, the use of energy efficient technologies, the types of energy conservation programs that are in place, whether the institution purchases renewable power, and whether there has been investment in renewable energy technology. The maximum points an institution can gain for each indicator varies across indicators and categories.

\footnotetext{
${ }^{6}$ The SEI Report Cards are available at http://www.greenreportcard.org (last accessed May 25, 2009).
} 
For each category, the institution is given a numerical grade which is then converted to a full letter grade - A though $\mathrm{F}$ with no plusses or minuses - according to a predetermined scale. The institution's overall sustainability grade is a non-weighted average of its letter grades in each of the eight individual categories and includes plusses and minuses. As shown in the grade distribution presented in Figure 1, six institutions - Carleton, Dartmouth, Harvard, Middlebury, the University of Vermont and the University of Washington - achieved an overall grade of Awhile four received a failing grade of $\mathrm{F}$ and an additional 19 scraped by with the minimum passing grade of a D-.

The indicators used by SEI for the 2008 report card encompass a wide range of practices, some of which will have a more direct or immediate effect on an institution than others. For example, in the Food and Recycling category IHEs receive points for buying from local farmers, eliminating the use of Styrofoam containers in dining halls, composting food and landscaping wastes, and increasing recycling rates on campuses. Institutions also receive points for completing a carbon emissions inventory, adopting sustainability-related mission statements, and providing internet resources on sustainability - practices which have a much less direct impact on environmental performance. However, to receive a relatively high grade, an institution would have to do more than just make general commitments to sustainability. For example, all six of the institutions receiving A- have recently built a structure on campus that received LEED certification and incorporate locally grown food in their dining halls, and five of the six purchase or generate significant quantities of energy from renewable sources.

The letter grades awarded by the SEI provide an ordinal measure of an institution's sustainability practices that can be used in the analysis. Because each grade represents an underlying range of numerical scores, the appropriate econometric model for the analysis is an 
ordered probit. The ordered probit model uses a limited dependent variable framework with a latent variable $G_{i}{ }^{*}$ that represents the true sustainability grade of institution $i . G_{i} *$ is determined as follows:

$$
G_{i}^{*}=\beta^{\prime} x_{i}+\varepsilon_{i}
$$

where $x_{i}$ is a vector containing the explanatory variables for institution $i, \beta$ is the vector of parameters to be estimated, and $\varepsilon_{i}$ is a random error term that is assumed to follow a standard normal distribution. ${ }^{7}$ In this model, the true grade $G_{i}{ }^{*}$ is not observed but the letter grade $K_{i}$ is observed. The ordered probit model assumes that $K_{i}$ depends on the true grade $G_{i}{ }^{*}$ as follows:

$$
K_{i}=\left\{\begin{array}{c}
A \text { if } G_{i}^{*}>\mu_{A} \\
B \text { if } \mu_{A} \geq G_{i}^{*}>\mu_{B} \\
C \text { if } \mu_{B} \geq G_{i}^{*}>\mu_{C} \\
D \text { if } \mu_{C} \geq G_{i}^{*}>\mu_{D} \\
F \text { if } \mu_{D} \geq G_{i}^{*}
\end{array}\right.
$$

where the $\mu$ 's are thresholds that determine the ordinal intervals of the scale and must be estimated. (If there are also plus and minus grades, there would be additional entries in the equation above and additional $\mu$ 's to be estimated.) In this model the probability that institution $i$ has a grade of $\mathrm{B}$, would be:

$$
\operatorname{Prob}\left[K_{i}=\mathrm{B}\right]=\operatorname{Prob}\left[\mu_{\mathrm{A}} \geq \beta^{\prime} x_{i}+\varepsilon_{i}>\mu_{\mathrm{B}}\right]=\Phi\left(\mu_{\mathrm{A}}-\beta^{\prime} x_{i}\right)-\Phi\left(\mu_{\mathrm{B}}-\beta^{\prime} x_{i}\right)
$$

where $\Phi$ is the standard normal cumulative distribution function. The other probabilities are defined analogously. The parameters $\beta$ and $\mu$ can then be estimated by maximum likelihood.

As discussed in Section 2, one would reasonably expect several different types of factors to affect an IHE's decision to implement sustainable practices. I have identified four broad categories of factors - regulatory pressures, financial constraints, student preferences, and stakeholder influences - that I think should have a significant affect on the adoption of campus

\footnotetext{
${ }^{7}$ See Wooldridge (2002) for a more detailed discussion of this model.
} 
sustainability. Note that these categories are generally analogous to the four basic categories of factors that affect corporate adoption of sustainable practices (regulatory pressures, financial and market constraints, consumer pressure, and pressure from other stakeholders) discussed in the literature review.

Table 2 lists the explanatory variables used in the analysis along with the variables' means and standard deviations. Because the 2008 Report Card was published in 2007, each institution's grade is based on practices and information from 2005 to 2007 . I have tried to match the explanatory data to this general period. Unless otherwise noted, the institutional data are for the 2005-06 school year and were collected from U.S. Department of Education's Integrated Postsecondary Education Data System (IPEDS). I have loosely organized the variables into the four categories listed above along with a fifth category of "Other Factors," although arguably some variables could fit into more than one category.

\subsection{Regulatory Pressures}

All IHEs in the U.S. are likely to be subject to some form of environmental regulation. For example, if the IHE has a chemistry department with laboratories either for teaching or research purposes, it is subject to some form of hazardous waste regulation. Additionally any IHE with a power plant is likely to be subject to regulation under the Clean Air Act. In the U.S. environmental regulations vary across states, with the federal government setting minimum standards that states can add to if they wish. Just as regulatory stringency has been shown to increase the adoption of sustainable practices by corporations, one might expect IHEs in states with more stringent environmental regulations to be more likely to adopt sustainable practices. ${ }^{8}$ However, it is difficult to measure regulatory stringency directly as there are many different facets of state environmental regulations. Thus I use the variable Regulatory Budget as a proxy

\footnotetext{
${ }^{8}$ See, for example, Henriques and Sadorsky (1996), Khanna and Anton (2002), and Khanna et al. (2007).
} 
for a states' environmental stringency. This variable measures the state expenditures on

environmental and natural resource programs according to the 2006 Survey of State Government Finances. ${ }^{9}$ It is normalized by the number of facilities in the state that are subject to federal environmental regulation. ${ }^{10}$

In addition to regulatory stringency, the degree to which a state enforces regulations will affect the adoption of sustainable practices if IHEs are motivated by a desire to avoid environmental violations. Enforcement Actions measures the number of enforcement actions taken against environmental violators in the state in 2006 for every 1,000 federally-regulated facilities in the state. The number of enforcement actions in 2006 was downloaded from EPA's Enforcement and Compliance History Online (ECHO) database. ${ }^{11}$ Inspection Rate is a related variable that measures the number hazardous waste inspections in 2005 in the state, normalized by the number of hazardous waste facilities. ${ }^{12}$ If regulatory pressures are significant drivers of campus sustainability efforts, Enforcement Actions and Inspection Rate should both have a positive effect on an institution's sustainability grade. One might also expect those IHEs that have the greatest environmental exposure to be more likely to adopt sustainable practices. Because the level of environmental exposure is directly related to the size of an institution, I use Total Students as a proxy for environmental exposure and expect a positive relationship.

\footnotetext{
${ }^{9}$ Available at http://www.census.gov/govs/www/state.html (last accessed February 27, 2008).

${ }^{10}$ EPA's Facility Registration System is a database of all facilities in the US subject to federal environmental regulation. Data on the number of regulated facilities in each state was taken from the October 2008 version of the database.

${ }^{11}$ Available at http://www.epa-echo.gov/echo/. Data downloaded on October 27, 2008.

${ }^{12}$ Data on the number of hazardous waste inspections and facilities in each state was taken from the February 2008 version EPA's RCRAInfo database. I use the hazardous waste program for two primary reasons. First, because environmental regulations are media-specific, it is difficult to obtain an overall environmental inspection rate. Second, the hazardous waste program is one of the largest environmental programs covering approximately 680,000 facilities in the US and as discussed above most IHEs in the US are subject to hazardous waste regulation.
} 


\subsection{Financial Constraints}

Financial constraints should be a significant factor in an IHE's adoption of sustainable practices just as financial pressures affect whether a corporation adopts a voluntary environmental program. However the nature of the financial constraints faced by IHEs is very different from that faced by corporations. The revenues for IHEs come primarily from tuition, donations, and research activities. Public institutions also receiving state funding. The variable Tuition captures the average annual tuition and fees per student, net of financial aid. I expect tuition to be positively related to an IHE's sustainability grade, as higher tuition will increase the financial resources available for implementing sustainable practices. I also include the variable Percent on Financial Aid which I expect to have a negative effect on an IHE's sustainability grade, as spending on financial aid decreases the funds available for other activities at an institution. ${ }^{13}$ To account for the fact that Public institutions are likely to receive some state funding in addition to tuition revenues, I include the dummy variable Public. One might also expect community pressures may be stronger for public institutions than private institutions and thus public institutions to invest more in sustainability than private institutions. On the other hand, public institutions may be more constrained by state procurement rules than private institutions, so it is not clear ex ante what the coefficient's sign should be.

To capture donations to an institution that support its operations, I include the institution's Endowment as reported in the SEI 2008 Report Card, normalized by the total number of full-time students. I expect this variable to have a positive effect on the institution's grade as a higher endowment implies fewer financial constraints. To capture the ability of an

\footnotetext{
${ }^{13}$ This variables includes all sources (federal, state, institutional) and types (need-based, merit, athletic) of aid. Given that institutional requirements for need-based aid are likely to be more generous than federal and state requirements and that federal and state merit-based aid programs are minimal, the percent of students on institutional aid is likely to be close to the percent of students on any form of aid.
} 
institution to supplement their revenues with research funding, I use the dummy variable High Research Activity which indicates whether an institution is classified by the Carnegie

Commission on Higher Education as conducting a high or very high level of research. ${ }^{14}$ Because institutions with high levels of research activity are likely to receive more external funding through grants than less active institutions, I expect this variable to have a positive effect on the implementation of sustainable practices. Finally, I include Electricity Cost to measure the extent to which an institution might adopt sustainable practices, particularly those that conserve energy, as a result of financial pressure, and I expect institutions in states with higher average electricity costs to be more likely to adopt sustainable practices. ${ }^{15}$

\subsection{Student Preferences}

Because IHEs compete for students, student preferences should have an effect on campus sustainability efforts just as consumer preferences affect corporate practices. Student preferences are difficult to measure, particularly since the preferences of potential students matter as much or perhaps more than the preferences of current students. Moreover there is very little publicly available data on student preferences across institutions. ${ }^{16}$ To address similar limitations with consumer preference data, analyses of corporate environmental performance have focused on market conditions as a proxy for consumer preferences. The more competitive a market is, the more a company will have to adjust its practices to be in line with consumer preferences. Analogously one might expect that institutions that have to compete for students to be more responsive to student preferences than schools that are in high demand.

\footnotetext{
${ }^{14}$ The technical details for classifying institutions in these categories can be found at http://www.carnegiefoundation.org/classifications/index.asp?key=798 (last accessed February 28, 2008).

${ }^{15}$ Data on the average retail price of electricity by state for 2007 was taken from "State Energy Data 2007: Prices and Expenditures" published by the Energy Information Administration of the Department of Energy.

${ }^{16}$ For example, the National Survey on Student Engagement captures experiences rather than preferences.
} 
Acceptance Rate is one of the measures of an institution's competitive position. I expect institutions with higher acceptance rates (i.e., schools that are less selective) to be more likely to adopt sustainable practices because the high acceptance rate indicates a need to attract more applicants. According to a 2006 MTV/CBS news poll of Americans aged 13 to 24, when asked to name the most important problem their generation will face in 20 years, respondents most often chose the environment and 81 percent stated that actions need to be taken immediately to counter global warming. ${ }^{17}$ Thus most college applicants are likely to be very concerned about this environment and one method of attracting applicants might be to implement sustainable practices.

The next two variables are dummies indicating whether the institution was highly ranked in 2007 by U.S. News and World Reports. The rankings differentiate between national institutions and liberal arts institutions: national institutions offer masters and doctoral degrees while liberal arts institutions emphasize undergraduate education and award at least 50 percent of their degrees in the arts and sciences. The dummies indicate whether the institution is ranked in the top 50 for each category. Because top ranked schools should attract more qualified candidates than lower ranked schools and they might be under less pressure to attract students with sustainability initiative. Alternatively, top ranked schools might feel more pressure to keep their ranking.

I expect students that live on campus to exert more pressure on an institution to adopt sustainable practices, particularly practices that affect residence halls and food services. The variable Percent On Campus reflects the percent of total students that live on campus according to Barron's 2005 Profile of American Colleges and I expect this variable to be positively related

\footnotetext{
${ }^{17}$ Results available at http://www.mtv.com/thinkmtv/about/pdfs/mtv_environment_poll.pdf (last accessed February 28, 2008)
} 
to the institution's sustainability grade. Because student pressure is likely to grow as students learn more about environmental issues and sustainability, the analysis includes the variable Environmental Major which indicates whether an IHE has an environmental studies or science major for the 2007-08 school year. ${ }^{18}$ I also expect this variable to have a positive effect on an institution's adoption of sustainable practices. Finally, I include two variables to measure the geographic diversity among the student body, Percent Out of State and Percent International. ${ }^{19}$

One might expect students that attend college out of state or in a different country to have a less parochial perspective than students who remain in state. Such students might be more attuned to global environmental issues and exert more pressure on administrators to adopt sustainable practices.

\subsection{Stakeholder Influences}

Students are not the only group that might influence an IHE to adopt sustainable practices. Other key stakeholders include the faculty, the alumni of the institution, and the community surrounding the institution. To capture faculty influence, I include the variable Fulltime Faculty which measures the percent of the faculty that have full-time as opposed to adjunct positions. Full-time faculty are likely to remain at the same institution for a longer time and thus may be more involved in administrative decisions. However, I have not been able to find any empirical evidence on whether faculty in general are supportive of sustainability. On my own campus there are mixed views about the relative importance of implementing sustainable practices given all of the other goals of the university. Thus I have no prior expectation on the sign of the coefficient on this variable. To measure alumni involvement, I use Alumni Giving

\footnotetext{
${ }^{18}$ These data were collected from the Peterson's website in December of 2007.

${ }^{19}$ These data were taken from the 2009 Edition of the Princeton Review's The Best 368 Colleges, published in 2008. For those schools not included in the list of the best 368 colleges (approximately 20 institutions) we collected the data from the Princeton Review website in December 2009.
} 
which measures the percent of alumni who annually give money to the institution. ${ }^{20}$ I also have no prior expectation about how alumni might influence an IHE's adoption of sustainable practices.

To measure community pressure, I include several county and state level variables. The first, Size Relative to County is the ratio of total students at the institution to the total population of the county in which the institution is located. ${ }^{21}$ Institutions that make up a large percentage of a county's population may be more subject to community pressure than institutions that represent a smaller portion of the local economy, so I expect a positive coefficient on this variable. Of course, the size variable will also depend on the overall size of counties - which varies widely across states - so I also include County Population as an explanatory variable. One might also expect community pressure for institutions to adopt sustainable practices to be greater in areas that are more highly educated. Thus I also include County Percent with Bachelor's to measure the education level in the county and I expect it to have a positive effect on the adoption of sustainable practices.

Of course, not all individuals will think that sustainability should be a high priority of IHEs. To measure community preferences for environmental quality, I include several statelevel variables. Environmental Organization Revenues measures the total revenues collected by environmental organizations in the state in 2005 , normalized by the state population. ${ }^{22}$ Individuals that contribute more to environmental organizations should also put more pressure on IHEs to implement sustainable practices, so I expect this variable to have a positive coefficient.

\footnotetext{
${ }^{20}$ These data were collected from the U.S. News and World Reports 2007 rankings. For each institution the variable measures the average percentage of living alumni who gave to their school during 2004-05 and 2005-06.

${ }^{21}$ The county-level data used in the analysis was taken from the 2007 County and City Data Book available on the Census Bureau's website (http://www.census.gov/statab/ccdb/ccdbstcounty.html).

${ }^{22}$ Data on environmental group revenues was obtained from the National Center for Charitable Statistics' Guidestar Database.
} 
The next variable, Federal Land, measures the percent of land in a state that is federally owned. ${ }^{23}$ This variable is a proxy for the importance of natural resources to a state and thus I expect it to be positively related to an IHE's sustainability grade. The final community variable, Percent Kerry, measures the percent of voters in the 2004 presidential election who voted for John Kerry, the Democratic candidate. ${ }^{24}$ I also expect this variable to have a positive effect on an IHE's sustainability grade.

\subsection{Other Factors}

There are a few additional factors that one might reasonably expect to affect an institution's decision to adopt sustainable practices but which are more difficult to categorize. School Growth Rate measures the percent increase in the total student body from 1990 to 2005. Schools that have grown significantly over that time period are likely to have built new buildings and thus have had more opportunities to incorporate energy efficient measures (for which they receive credit) on campus than schools that have not expanded. Percent Women controls for variation in the student bodies of IHEs, and is included because there appears to be a general sense that women are more interested in the environment than men, although the empirical evidence on this point is quite mixed. ${ }^{25}$ Religious indicates whether an institution has a religious affiliation. I include this variable because religious institutions may face different constraints than secular institutions. For example, dining hall policies may be dictated by religious beliefs rather than environmental concerns. While such constraints may affect an institution's practices, I have no specific expectation as to whether sustainability will be more or less difficult to adopt.

\footnotetext{
${ }^{23}$ These data were developed by the Bureau of Land Management (BLM) using data from 1995 and are available at http://www.blm.gov/natacq/pls97/1-3-97h.html (last accessed March 3, 2008). The BLM no longer provides this data in its Public Land Statistics publication.

${ }^{24}$ These data are available from the Federal Election Commission at http://www.fec.gov/pubrec/fe2004/tables.pdf (last accessed February 29, 2008). I experimented with other measures of state ideology such as the measures developed in Berry et al. (1998), but found Percent Kerry to have the greatest explanatory power. Additionally, the state-level measure of Percent Kerry had more explanatory power than an analogous county-level measure.

${ }^{25}$ See Torgler, Garcia-Valinas, and Macintyre (2008) for a discussion of the evidence.
} 
For the next variable, State System, I expect a positive effect on the sustainability grade. For some state university systems (such as the University of California), SEI only provided a single grade which, though based primarily on an evaluation of the flagship campus, does include practices on other campuses as well. I believe that notable practices at non-flagship campuses will be used to increase the flagship university's grade but that a lack of practices at these other campuses will not result in a lower grade. Thus I expect the grade for institutions representing state systems to be upwardly biased. I also added dummy variables for various regions of the U.S. (South, New England, Southwestern, and Western) with the Midwest as the omitted region.

\section{Results}

SEI 2008 report card included the 200 institutions in the U.S. and Canada with the highest overall endowments. Only 180 institutions are included in this analysis. First, because much of the data for this analysis were collected from the U.S. Department of Education's IPEDS database, the 5 Canadian institutions are not included. Second, for an additional 15 institutions data on some key institutional or locational characteristics were missing. ${ }^{26}$ The institutions excluded from the analysis and marked in Table 1 with an asterisk.

The results for the ordered probit regression are presented in column I of Table 3. Because the explanatory variables include state variables, I estimated robust standard errors clustered by state. First consider the variables that measure the regulatory pressures faced by the IHE. Neither of the coefficients on Regulatory Budget or Enforcement Effort is significant. While the coefficient on Inspection Rate is significant, it is negative. I had expected a high

\footnotetext{
${ }^{26}$ This includes four institutions located in the District of Columbia for which there are no state data. There does not appear to be any systematic explanation for who is missing data, as the remaining 11 omitted institutions include both large and small schools and both public and private institutions.
} 
inspection rate to prompt institutions to adopt sustainability, but it might be the case that states that focus their resources on compliance inspections have fewer resources available to help institutions go beyond compliance and adopt a wide range of sustainable practices. Note that these results contrast with the results from most studies of for-profit corporations where regulatory pressures do play a significant role in the adoption of sustainable practices.

The coefficient on Total Students is significant and has the expected positive sign. This result is consistent with the belief that IHEs with more environmental exposure will be more likely to adopt sustainable practices. It may also be the case that large IHEs are better able to achieve economies of scale in adopting sustainable technologies than smaller institutions. This result is consistent with the findings of the corporate sustainability literature but is not consistent with the view that small institutions are in a better position to implement sustainable practices than large institutions because they are more nimble and it is easier to achieve consensus on particular ideas. $^{27}$

Several of the financial constraint variables, Tuition, Percent on Financial Aid, Public, and Endowment, have positive and significant coefficients. The positive coefficients on both Tuition and Endowment are consistent with expectations. These two variables are arguably the most important two financial constraints, as they most directly measure an institution's wealth level. Not surprisingly, wealthier institutions are more likely to adopt sustainable practices. The positive coefficient on Percent on Financial Aid suggests that financial aid does not necessarily compete with sustainability for funding as anticipated. Finally, the positive coefficient on Public could indicate either that the support that public institutions receive from state governments

\footnotetext{
${ }^{27}$ See for example, comments from President David Hales of the College of the Atlantic reported on the Chronicle of Higher Education's website (http://chronicle.com/blogs/architecture/1249/college-of-the-atlantic-is-the-firstinstitution-to-achieve-climate-neutrality) (last accessed May 28, 2008).
} 
allows them to invest in more sustainable practices or that these institutions face more social pressure to adopt sustainable measures because they are public institutions.

Interestingly, only two variables proxying for student preferences have a significant coefficient, Percent Out of State and Percent International. This result is consistent with idea that that students from more diverse geographical backgrounds might also be more aware of and interested in environmental sustainability. However, there is no evidence to support my initial supposition that less selective institutions might use sustainability to try to attract more students. Admittedly the variables used in this analysis are only rough proxies for student preferences because it is difficult to measure such preferences directly, and the lack of significance could be due in part to multicollinearity. But another explanation for these results is that institutions are not currently using sustainability to increase student interest in the same way that companies are trying to market sustainability to their customers.

In contrast, several of the variables proxying for stakeholder interest are significant. The coefficient on Full-time Faculty is positive and significant indicating that schools with a larger percentage of full-time faculty (as opposed to part-time and adjunct faculty) are more likely to adopt sustainable practices. This result is consistent with the idea that many individuals prefer to work for employers who value the environment as well as the belief that full-time faculty are in a better position than part-time faculty to demand sustainable practices. ${ }^{28}$ The positive and significant coefficient on Alumni Giving is consistent with the idea that actively engaged alumni may exert pressure on an administration to become sustainable. Additionally, alumni giving may reflect lower financial constraints as alumni giving will increase an institution's financial resources.

${ }^{28}$ A 2004 Stanford Business School survey of graduating MBA students found that $94 \%$ would give up as much as $\$ 13,700$ a year of salary to work for a company that made corporate responsibility, including commitment to sustainability, a priority (Esty and Winston (2006), p. 90). 
All three county variables have significant coefficients. The positive coefficient on Size Relative to County suggests that institutions that make up a large percentage of a county's population are more subject to community pressure while the negative coefficient on County Population suggests that there is less pressure in large counties than in small ones. Also, the positive coefficient on County Percent with Bachelor's suggests that more educated communities are more likely to pressure institutions to adopt sustainable practices. The positive and significant coefficient on Federal Land suggests that an institution's decision to adopt sustainable practices may be related to the presence and importance of natural resources in the surrounding area.

Several of the "other factors" also have a significant effect on an institution's overall sustainability grade. As expected, there is a positive and significant coefficient on School Growth Rate indicating that schools that have grown significantly in the recent past may have had more opportunities to incorporate energy efficient measures than schools that have not expanded. The positive and significant coefficient on Percent Women shows that the higher the percentage of women on campus, the higher the institution's sustainability score which is consistent with the popular belief that women are more interested in the environment than men. Also, as expected those institutions that are graded based on the environmental practices of the entire state university system have higher overall grades than single-campus institutions as indicated by the positive and significant coefficient on State System. Finally, the positive and significant coefficient on New England indicates that institutions in New England are more likely to adopt sustainable practices than institutions in the Midwest (the omitted region).

One concern in interpreting these results is that much of the data used to develop the SEI grades are self-reported. As mentioned earlier, SEI collects some of the information necessary to 
grade each institution from some third party sources such as the EPA and the U.S. Green Building Council, but much of the data comes from the institution itself via its website, institutional press releases, and campus responses to SEI surveys. SEI sends a general survey to both the institution's president and, where applicable, sustainability coordinator and a separate dining service survey to the director of dining services. Of the institutions in this analysis, 110 responded to both surveys, 35 responded to the general campus survey alone, 10 responded to the dining survey alone, and 25 responded to neither. One might expect institutions who respond to the survey to receive higher grades because SEI has more information about sustainability practices at those institutions. Of course, institutions with more sustainable practices are also more likely to respond to the survey. Ideally I would use an instrumental variables approach to try to deal with the potential for a non-response bias, but unfortunately I have not been able to find any suitable instruments. Thus to better understand how the non-response could be biasing the results I present two additional ordered probit regressions.

The regression reported in column II of Table 3 includes two additional dummies, one indicating whether the institution completed the general campus survey and one indicating whether the institution completed the dining survey. The coefficients on both are positive and significant, as one would expect for both of the reasons discussed above. Note however, that there is no qualitative change in the signs of any of the significant coefficients for the other explanatory variables, although three variables that were significant are no longer individually significant (County Population, School Growth Rate, and Federal Land). The regression reported in column III of Table 3 reports the results of the ordered probit regression only for those institutions which completed the general campus survey. ${ }^{29}$ Obviously, there is an issue of

\footnotetext{
${ }^{29}$ There are some statistically significant differences between the respondents to the general survey and those that did not respond. I conducted t-tests on the difference between the means for each of the explanatory variables, and
} 
selection bias for these institutions. However, it is interesting to note that the results for this regression are not that dissimilar to the results presented in column I. Some variables that are not significant for the full sample are significant in the restricted sample and vice versa, but the signs of the coefficients are generally consistent. Overall, the findings are quite similar - financial constraints are significant drivers of the decision to adopt sustainability as are stakeholder interests. Contrary to expectations, regulatory pressures do not have positive effect on overall sustainability and there is no evidence that institutions are attempting to attract students with sustainable practices.

To assess how well the ordered probit regression explains an institution's grade, I use the estimated coefficients to predict each institution's sustainability grade. First I compute the estimated $\beta^{\prime} x_{i}$ for each institution. Recall that the ordered probit also estimates the "cutoff" points for each grade, the $\mu$ parameters. Using these parameters, I compute the probability that each institution would receive each possible grade using equation (2) on page 12. For example, Agnes Scott College (the first institution alphabetically) received a C from the SEI. According the estimated model, the probability that Agnes Scott would receive a C is $28 \%$, while the probability it would receive a $\mathrm{C}+\mathrm{is} 17 \%$ and the probability it would receive a $\mathrm{C}$ - is $22 \%$. On the higher end, the probability of receiving a $\mathrm{B}$ - is $10 \%$, the probability of a $\mathrm{B}$ is $2 \%$ and the probability of a $\mathrm{B}+$ or $\mathrm{A}$ - less than one percent. On the lower end, the probability of a $\mathrm{D}+$ is $11 \%$, the probability of a $\mathrm{D}$ is $5 \%$, the probability of a $\mathrm{D}$ - is $4 \%$ and the probability of an $\mathrm{F}$ is less than one percent. Figure 2 compares the distribution of actual grades to the distribution of predicted grades weighted by the probability of receiving each grade. As you can see, the predicted grades are quite close to the actual grades, although the C's are predicted more often

found that five of the 31 have a statistically significant difference (at the $95 \%$ confidence level): respondents have a lower Percent on Financial Aid, higher Endowment, Percent Out of State, and Alumni Giving and are more likely to be in the Top 50 National group. 
then they actually occur. (Recall that only 180 of 200 institutions are included in the analysis, so the distribution of actual grades varies slightly between Figures 1 and 2.)

It is also important to get a sense of the relative size of the effects that each of the explanatory variables has on the overall sustainability score. As is the case with an ordinary probit, the coefficients in an ordered probit are not equivalent to the marginal effects of the explanatory variables. The effect a change in an explanatory variable would have differs across institutions depending on the initial starting point. For example, even a significant increase in endowment might have no effect on an institution that is already receiving an A-, while a modest increase in endowment for a school currently receiving a D- could make a substantial difference. However, one can compare the effects of explanatory variables relative to each other. To do this, for each institution I calculate how the predicted probability of receiving each grade changes for a one-standard-deviation increase in each continuous explanatory variable. To calculate the effect of binary variables, I first calculate the grade distribution setting the binary variable to 0 and then recalculate the grade distribution setting the binary variable to 1 . To illustrate, Figure 3 shows the change in the overall predicted grade distribution for the sample for a one standard deviation increase in School Growth Rate compared to a one standard deviation increase in Alumni Giving. As shown, for both variables the probability of receiving grades of a $\mathrm{C}+$ and higher increases, while the probability of receiving grades of $\mathrm{C}$ or less decreases. However, Alumni Giving has a much larger effect on the probability distribution than School Growth Rate.

To facilitate comparisons across variables, I convert each grade distribution to an average grade using a 4.0 scale (i.e., an $\mathrm{A}-=3.7$, a $\mathrm{B}+=3.3$, a $\mathrm{B}=3.0$, etc.). Table 4 shows the average grade change for each explanatory variable with a significant coefficient. Of the continuous variables, Alumni Giving has the largest effect followed closely by Federal Land while School 
Growth Rate had the smallest. Of the two binary variables, State Systems has a quantitatively larger effect than Public.

As discussed in the previous section, in my opinion the SEI evaluation process does require institutions to be making real investments in adopting sustainable practices, and not merely making symbolic gestures toward sustainability (although admittedly it does give some credit for what could be merely symbolic gestures). Just as the literature on corporate sustainability tries to differentiate between true environmental improvements and "greenwashing" practices (i.e., practices that merely give the appearance of sustainability), I also want to better understand the factors that affect adopting of sustainable practices compared to actions that might appear to be sustainable, but have less impact on an institution's true environmental performance. To do this, I also examine institutional decisions to sign the American College and University Presidents Climate Commitment (PCC). The PCC is a relatively well-publicized initiative launched in 2007 to get presidents of IHEs to commit to making their campuses more sustainable and to reduce campus greenhouse gas emissions. ${ }^{30}$ The PCC has partnered with the William J. Clinton Foundation and has been covered in national news outlets including the New York Times, Newsweek, and Time magazine. Additionally most signatories to the PCC issue a press release which is covered by the local, if not the national, media.

Presidents who sign the PCC commit to develop "a comprehensive plan to achieve climate neutrality as soon as possible." Presidents also commit to initiating two or more "tangible actions to reduce greenhouse gases" in the future. While I am sure that many signatories to the PCC are taking real steps to reduce greenhouse gas emissions, I do not believe

\footnotetext{
${ }^{30}$ Information on the PCC is available at http://www.presidentsclimatecommitment.org (last accessed May 26, 2009).
} 
that all of those signing the PCC are making significant investments in adopting sustainable practices. For example, as shown in Figure 4, 5 of the 16 institutions receiving a D- from SEI were signatories to the PCC as of January 2009, roughly the same percentage of those receiving a B+.

Table 5 presents the results of a probit regression where the dependent variable is equal to 1 if the IHE's president had signed the PCC as of January 2009. The explanatory variables used in this analysis are the same as those used in the ordered probits reported in Table 3 and the standard errors are clustered by state. Note that only four of the coefficients are significant, those on Inspection Rate, Electricity Cost, Top 50 Liberal Arts and Federal Land. Unlike the results for the SEI grade, the coefficient on Inspection Rate is positive indicating that institutions in states with higher levels of regulatory enforcement are more likely to participate in the PCC. One possible explanation for this inconsistency could be that regulatory pressures are sufficient to drive institutions to adopt symbolic gestures, but not enough to get them to implement sustainable practices that require scarce resources. The positive coefficient on Electricity Cost indicates that institutions in areas with higher electricity costs are more likely to sign the PCC. This result is not surprising as many of the actions that an institution can take to reduce greenhouse gas emissions would also reduce energy consumption.

Note that the coefficient on Total Students is not significant. This suggests that there are not significant economies of scale associated with signing the PCC although there are likely to be such economies of scale with other types of sustainable practices. The most striking result is that neither Tuition or Endowment has a significant coefficient in this regression. Thus, while taking real steps to adopt sustainable practices appears to depend largely on financial resources, making commitments to sustainability does not. This suggests that the commitments made under 
the PCC may not actually result in significant improvements in a campus's environmental performance.

\section{Conclusions}

While there are obviously many factors that drive institutions to embrace sustainable practices, the most consistent and robust finding of this analysis is that sustainability appears to be something of a luxury good in higher education. Larger and wealthier institutions are more likely to adopt sustainability than smaller, less well-endowed institutions. Thus while in theory IHEs may be able to make long-term investments in sustainability that corporations would not find profitable in the short-run, financial resources still play a significant role in the adoption of sustainable practices on campus. In contrast, wealth and size do not appear to be significant drivers of symbolic gestures of sustainability, as evidenced by the results for the Presidents Climate Commitment.

Although there is clearly a lot of enthusiasm for sustainability among students on many campuses, this study found no evidence that IHEs are currently adopting sustainable practices as a way of competing for students. Admittedly the variables used in the analysis are only rough proxies for student preferences because it is difficult to measure student preferences directly. But it is also likely that while high school and college students strongly believe that the environment is important, environmental practices do not significantly affect the college selection decision. This is not to say that individual students do not affect campus sustainability efforts - once on campus they may actively work to improve the environment of the campus - but the key is that environmental preferences may not be an important factor in the decision of where to go to college. 
In contrast to the findings of the corporate sustainability literature, regulatory pressures do not play an important role in encouraging sustainability on campus, although larger institutions - those with greater environmental liabilities - are more likely to adopt sustainable practices than small institutions. This result may indicate that there are economies of scale in adopting sustainable practices but is inconsistent with the idea that smaller campuses are better able to implement sustainability than large campuses. The finding that regulatory pressure is not be an important driver for campus sustainability may be due to the fact that the baseline level of regulatory pressure is much lower for IHEs than for companies in general. However, this difference also implies that if policy makers wish to encourage sustainability on campus, they will need to use different policies than they use for corporations because they will not be able to use regulatory pressure to effect changes in practices.

For IHEs, stakeholders - alumni, faculty, and the community - appear to play a more dominant role in encouraging the adoption of sustainable practices than they do for corporations. This is not to imply that corporate stakeholders - investors and the community - are insignificant factors in corporate sustainability. For example, Khanna and Anton (2002) find that firms that are more dependent on the market for capital are more likely to adopt EMS and Welch, Mazur, and Bretschneider (2000) find that utilities headquartered in state with higher levels of environmental activism are more likely to enroll in the Department of Energy's Climate Challenge Program. However, corporate stakeholders are not a significant factor in many studies of corporate sustainability. In contrast, the results of this study suggest that policy makers may be able to engage IHE stakeholders such as faculty and alumni in helping to increase sustainable practices on campuses. However, given the findings that size and wealth are important factors in achieving sustainability, it is likely that programs that subsidize campus sustainability efforts or 
provide technical assistance to smaller institutions might be the most successful at encouraging campuses to adopt practices that actually make an institution more sustainable as opposed to practices that might merely help an institution appear more sustainable.

While the specific results of this study obviously apply only to IHEs, the general findings should also be relevant for non-profits in general. I would expect stakeholders to play a more dominant role in environmental decision making at all types of non-profits than they do at forprofit corporations. Additionally, I expect that regulatory pressure will have relatively little effect on the adoption of sustainable practices in the wider non-profit universe. However, I think it is likely that financial incentives and technical assistance for small institutions could prove to be effective at increasing sustainability at non-profits in general, as I anticipate the findings that financial resources and size are important drivers of sustainable practices would carry over to other non-profits as well. 


\section{References}

Berry, William D., Evan J. Ringquist, Richard C. Fording, Russell L. Hanson. 1998. "Measuring Citizen and Government Ideology in the American States, 1960-1993," American Journal of Political Science, 42(1):372-348.

Cabaniss, Amy. 2006. "Connecticut College State of the Environment Report for 2005-2006," available at http://www.yale.edu/sustainability/necsc/Sustainability\%20Strategy/ conncoll\%20state\%20of\%20the\%20enviro.pdf.

Clotfelter, Charles T. 1996. Buying the Best: Cost Escalation in Elite Higher Education. Princeton, NJ: Princeton University Press.

Cohn, Elchanan, Sherrie L.W. Rhine, and Maria C. Santos. 1989. "Institutions of Higher Education as Multi-Product Firms: Economies of Scale and Scope," Review of Economics and Statistics, 72(2): 284-290.

Creighton, Sarah H. 1998. Greening the Ivory Tower: Improving the Environmental Track Record of Universities, Colleges and Other Institutions. Cambridge, MA: The MIT Press.

Esty, Daniel C. and Andrew S. Winston. 2006. Green to Gold: How Smart Companies Use Environmental Strategy to Innovate, Create Value, and Build Competitive Advantage. New Haven, CT: Yale University Press.

Gunningham, Neil, Robert A. Kagan, and Dorothy Thornton. 2004. "Social License and Environmental Protection: Why Businesses Go Beyond Compliance," Law and Social Inquiry, 29(2):307-321.

Henriques, Irene and Perry Sadorsky. 1996. "The Determinants of an Environmentally Responsive Firm: An Empirical Approach," Journal of Environmental Economics and Management, 30(3):381-395.

Hopkins, David S. P. and William F. Massy. 1981. Planning Models for Colleges and Universities. Stanford, C: Stanford University Press.

Khanna, Madhu and Wilma Rose Q. Anton. 2002. "Corporate Environmental Management: Regulatory and Market-Based Incentives," Land Economics, 78(4):539-558.

Khanna, Madhu and Keith Brouhle. 2008. "Effectiveness of Voluntary Environmental Initiatives," forthcoming in Governing and the Environment: Interdisciplinary Perspectives, M. Delmas and O. Young, eds.

Khanna, Madhu, Patricia Koss, Cody Jones, and David Ervin. 2007. "Motivations for Voluntary Environmental Management," Policy Studies Journal, 35(4):751-772. 
Martin, Robert E. 2005. Cost Control, College Access, and Competition in Higher Education. Northampton, MA: Edward Elgar.

Potoski, Matthew and Aseem Prakash. 2005. "Green Clubs and Voluntary Governance: ISO 14001 and Firms’ Regulatory Compliance,” American Journal of Political Science, 49(2): 235-248.

Sharp, Leith. 2002. "Green Campuses: The Road from Little Victories to Systematic Transformation," International Journal of Sustainability in Higher Education, 3(2): 128145.

Torgler, Benno, Maria A. Garcia-Valinas, and Alison Macintyre. 2008. "Differences in Preferences Toward the Environment: The Impact of Gender, Age, and Parental Effect," Queensland University of Technology Working Paper 221.

Velazquez, Luis, Nora Munguia and Margarita Sanchez. 2005. "Deterring Sustainability in Higher Education Institutions: An Appraisal of the Factors Which Influence Sustainability in Higher Education Institutions," International Journal of Sustainability in Higher Education, 6(4): 383-391.

Welch, Eric W., Allan Mazur, and Stuart Bretschneider. 2000. "Voluntary Behavior by Electric Utilities: Levels of Adoption and Contribution by the Climate Challenge Program to the Reduction of Carbon Dioxide," Journal of Policy Analysis and Management, 19(3): 407425.

Wooldridge, Jeffrey M. 2002. Econometric Analysis of Cross Section and Panel Data. Cambridge, MA: The MIT Press.

Yale University. 2005 "Yale University Environment Report: 1997-1998 through 2003-2004," available at http://www.yale.edu/sustainability/necsc/Sustainability\%20Strategy/ envreport\%20yale.pdf. 


\section{Table 1. Sustainability Grades from SEI's 2008 College Sustainability Report Card}

\begin{tabular}{|c|c|c|c|c|c|}
\hline Agnes Scott College & $\mathrm{C}$ & Grinnell College & B & Rollins College & $\mathrm{D}+$ \\
\hline American University* & $\mathrm{D}+$ & Hamilton College & $\mathrm{C}+$ & Rush University & D- \\
\hline Amherst College & B & Harvard University & A- & Rutgers University & $\mathrm{C}$ \\
\hline Arizona State University & B- & Haverford College & $\mathrm{C}$ & Saint Louis University & D- \\
\hline Auburn University & $\mathrm{D}+$ & Howard University* & $\mathrm{F}$ & Samford University & $\mathrm{F}$ \\
\hline Bates College & B- & Illinois Institute of Tech. & $\mathrm{D}$ & Santa Clara University & B- \\
\hline Baylor University & $\mathrm{C}-$ & Indiana University & $\mathrm{C}$ & Sewanee & $\mathrm{C}$ \\
\hline Berea College & $\mathrm{C}+$ & Iowa State University & $\mathrm{C}$ & Smith College & B- \\
\hline Berry College & $\mathrm{D}+$ & Johns Hopkins University & B- & Southern Methodist University & $\mathrm{C}-$ \\
\hline Boston College & $\mathrm{C}$ & The Juilliard School* & $\mathrm{F}$ & Southwestern University & D+ \\
\hline Boston University & $\mathrm{C}$ & Kansas State University & D+ & Spelman College & D- \\
\hline Bowdoin College & B- & Lafayette College & D- & St. John's University (NY) & $\mathrm{C}-$ \\
\hline Brandeis University & $\mathrm{C}$ & Lehigh University & D+ & St. Lawrence University & B- \\
\hline Brown University & $\mathrm{B}+$ & Louisiana State University & $\mathrm{C}-$ & St. Olaf College & $\mathrm{C}-$ \\
\hline Bryn Mawr College & $\mathrm{C}+$ & Loyola Marymount University & $\mathrm{D}+$ & Stanford University & $\mathrm{B}+$ \\
\hline Bucknell University & $\mathrm{C}-$ & Loyola University of Chicago & C- & Swarthmore College & B- \\
\hline California Institute of Tech. & $\mathrm{C}$ & Loyola Univ. of New Orleans* & D- & Syracuse University & B- \\
\hline Carleton College & A- & Macalester College & $\mathrm{B}$ & Texas A \& M University & $\mathrm{C}-$ \\
\hline Carnegie Mellon University & B- & Marquette University & D- & Texas Christian University & $\mathrm{D}+$ \\
\hline Case Western Reserve & $\mathrm{C}$ & Massachusetts Institute of Tech. & $\mathrm{B}+$ & Texas Tech University & $\mathrm{D}$ \\
\hline Claremont McKenna College & $\mathrm{C}-$ & McGill University* & B- & Trinity University (TX) & D- \\
\hline Clark University & B & Miami University & $\mathrm{D}+$ & Tufts University & $\mathrm{B}+$ \\
\hline Clemson University & $\mathrm{C}+$ & Michigan State University & B & Tulane University* & $\mathrm{C}$ \\
\hline Colby College & $\mathrm{C}+$ & Middlebury College & A- & Union College (NY) & $\mathrm{C}+$ \\
\hline Colgate University & $\mathrm{D}+$ & Mississippi State University & $\mathrm{D}$ & State University of New York & B- \\
\hline College of the Holy Cross & $\mathrm{C}$ & Mount Holyoke College & B- & University of Alabama & $\mathrm{D}+$ \\
\hline College of the Ozarks & D- & National University* & D- & University of Alaska* & $\mathrm{C}-$ \\
\hline College of William \& Mary & D- & New York University & $\mathrm{C}+$ & University of Alberta* & $\mathrm{C}$ \\
\hline Colorado College & $\mathrm{C}$ & North Carolina State Univ. & $\mathrm{D}$ & University of Arizona & $\mathrm{C}+$ \\
\hline Columbia University & B & Northeastern University & B & University of Arkansas & $\mathrm{C}$ \\
\hline Cornell University & $\mathrm{B}$ & Northwestern University & $\mathrm{C}+$ & Univ. of British Columbia* & $\mathrm{B}+$ \\
\hline Creighton University* & $\mathrm{D}$ & Oberlin College & $\mathrm{B}+$ & University of California & $\mathrm{B}+$ \\
\hline Dartmouth College & A- & Occidental College & $\mathrm{D}+$ & University of Chicago & $\mathrm{C}-$ \\
\hline Davidson College & C- & Ohio State University & $\mathrm{C}+$ & University of Cincinnati & $\mathrm{C}+$ \\
\hline Denison University & $\mathrm{D}$ & Oklahoma State University & $\mathrm{D}+$ & University of Colorado & B- \\
\hline DePaul University & D- & Olin College of Engineering* & D- & University of Connecticut & $\mathrm{C}$ \\
\hline DePauw University & $\mathrm{D}+$ & Oregon State University & B- & University of Dayton & D+ \\
\hline Dickinson College & $\mathrm{B}+$ & Pennsylvania State University & B & University of Delaware & $\mathrm{C}-$ \\
\hline Drew University & $\mathrm{D}+$ & Pepperdine University & D- & University of Florida & B- \\
\hline Drexel University & $\mathrm{C}-$ & Pomona College & B & University of Georgia & $\mathrm{D}$ \\
\hline Duke University & $\mathrm{B}+$ & Princeton University & B- & University of Houston & $\mathrm{D}$ \\
\hline Earlham College & $\mathrm{C}+$ & Purdue University & $\mathrm{C}$ & University of Illinois & B- \\
\hline Emory University & B- & Queens University* & $\mathrm{C}$ & University of Iowa & B- \\
\hline Florida State University & $\mathrm{C}-$ & Reed College & $\mathrm{C}+$ & University of Kansas & $\mathrm{C}-$ \\
\hline Fordham University & $\mathrm{D}$ & Regent University* & $\mathrm{F}$ & University of Kentucky & $\mathrm{C}$ \\
\hline Franklin \& Marshall College & $\mathrm{C}$ & Rensselaer Polytechnic Institute & C- & University of Louisville & $\mathrm{C}+$ \\
\hline Furman University & B- & Rhode Island School of Design & $\mathrm{C}$ & University of Maryland & $\mathrm{C}+$ \\
\hline George Washington Univ.* & D+ & Rhodes College & $\mathrm{C}-$ & University of Massachusetts & $\mathrm{C}+$ \\
\hline Georgetown University* & B- & Rice University & $\mathrm{C}+$ & University of Miami & $\mathrm{C}+$ \\
\hline Georgia Institute of Tech. & $\mathrm{C}$ & Rochester Institute of Tech. & D- & University of Michigan & $\mathrm{B}+$ \\
\hline Gettysburg College & D- & The Rockefeller University* & $\mathrm{C}$ & University of Minnesota & B \\
\hline
\end{tabular}




\begin{tabular}{|ll|ll|l|l|}
\hline University of Mississippi* & D- & University of St. Thomas & C- & Wabash College & D- \\
University of Missouri & C & University of Tennessee & C+ & Wake Forest University \\
University of Nebraska & D+ & University of Texas & B- & Washington and Lee Univ. & B- \\
University of New Hampshire & B & University of Toronto* & B & Washington State University & C+ \\
University of New Mexico & C & University of Tulsa & D & Washington Univ. in St. Louis C & C+ \\
University of North Carolina & B- & University of Utah & C & Wellesley College & B \\
University of Notre Dame & C & University of Vermont & A- & Wesleyan University \\
University of Oklahoma & C & University of Virginia & B- & West Virginia University \\
University of Oregon & B- & University of Washington & A- & Wheaton College (IL) \\
University of Pennsylvania & B & University of Wisconsin & B+ & Whitman College & C- \\
University of Pittsburgh & C- & University of Wyoming & C & Willamette University \\
University of Richmond & C & Vanderbilt University & C+ & Williams College \\
University of Rochester & C & Vassar College & B- & Worcester Polytechnic Institute D- \\
University of South Alabama & D- & Villanova University & C & Yale University & B+ \\
University of South Florida & D- & Virginia Commonwealth Univ. & D- & Yeshiva University \\
Univ. of Southern California & C + & Virginia Polytechnic Institute & C- & \\
\hline
\end{tabular}

*Not included in analysis due to missing data. 
Table 2: Explanatory Variables Used in the Analysis

\begin{tabular}{|c|c|c|c|}
\hline Variable Name & Description & Mean & $\begin{array}{l}\text { Std. } \\
\text { Dev. }\end{array}$ \\
\hline \multicolumn{4}{|c|}{ Regulatory Pressures } \\
\hline $\begin{array}{l}\text { Regulatory } \\
\text { Budget }\end{array}$ & $\begin{array}{l}\text { State budget for environmental programs normalized by number of } \\
\text { regulated facilities. }\end{array}$ & 9.51 & 8.72 \\
\hline $\begin{array}{l}\text { Enforcement } \\
\text { Actions }\end{array}$ & $\begin{array}{l}\text { Number of environmental enforcement actions in the state per thousand } \\
\text { regulated facilities. }\end{array}$ & 3.58 & 2.24 \\
\hline Inspection Rate & $\begin{array}{l}\text { Number of hazardous waste inspections in the state normalized by } \\
\text { number of hazardous waste facilities. }\end{array}$ & 0.02 & 0.01 \\
\hline Total Students & Number of students (all levels), in thousands. & 14.76 & 13.13 \\
\hline \multicolumn{4}{|c|}{ Financial Constraints } \\
\hline Tuition & Average annual tuition and fees net of financial aid, in thousands. & 14.38 & 6.58 \\
\hline $\begin{array}{l}\text { Percent on } \\
\text { Financial Aid }\end{array}$ & Percent of students receiving some form of financial aid. & 73.49 & 15.37 \\
\hline Public & Dummy variable equal to 1 if institution is public. & 0.36 & 0.48 \\
\hline Endowment & $\begin{array}{l}\text { Institution's endowment, in billions normalized by the number of full- } \\
\text { time students. }\end{array}$ & 0.23 & 0.34 \\
\hline $\begin{array}{l}\text { High Research } \\
\text { Activity }\end{array}$ & $\begin{array}{l}\text { Dummy equal to } 1 \text { if facility is classified as "very high" or "high" } \\
\text { research activity by the Carnegie Commission. }\end{array}$ & 0.61 & 0.49 \\
\hline Electricity Cost & Average state electricity cost (\$ per million BTUs) in 2007. & 29.46 & 9.62 \\
\hline \multicolumn{4}{|c|}{ Student Preferences } \\
\hline Acceptance Rate & Percent of applicants accepted for enrollment. & 54.16 & 22.62 \\
\hline Top 50 National & $\begin{array}{l}\text { Dummy equal to } 1 \text { if institution is a top } 50 \text { National University in the } \\
2007 \text { US News \& World Report rankings. }\end{array}$ & 0.24 & 0.43 \\
\hline $\begin{array}{l}\text { Top } 50 \text { Liberal } \\
\text { Arts } \\
\end{array}$ & $\begin{array}{l}\text { Dummy equal to } 1 \text { if the institution is a top } 50 \text { Liberal Arts Institutions } \\
\text { in the } 2007 \text { US News \& World Report rankings. }\end{array}$ & 0.22 & 0.41 \\
\hline $\begin{array}{l}\text { Percent On } \\
\text { Campus }\end{array}$ & Percent of total students living on campus. & 0.58 & 0.30 \\
\hline $\begin{array}{l}\text { Environmental } \\
\text { Major } \\
\end{array}$ & $\begin{array}{l}\text { Dummy equal to } 1 \text { if the school has an environmental sciences or } \\
\text { studies major. }\end{array}$ & 0.30 & 0.46 \\
\hline $\begin{array}{l}\text { Percent Out of } \\
\text { State }\end{array}$ & Percent of students who reside out of state. & 0.48 & 0.28 \\
\hline \begin{tabular}{|l|} 
Percent \\
International
\end{tabular} & Percent of students who are not U.S. residents. & 0.04 & 0.03 \\
\hline \multicolumn{4}{|c|}{ Stakeholder Influences } \\
\hline Full-time Faculty & Percent of faculty that are full-time. & 90.32 & 7.01 \\
\hline Alumni Giving & Percent of alumni who give to the institution. & 27.46 & 14.37 \\
\hline $\begin{array}{l}\text { Size Relative to } \\
\text { County }\end{array}$ & Total students divided by county population (in thousands). & 0.99 & 0.97 \\
\hline \begin{tabular}{|l|l|} 
County \\
Population
\end{tabular} & County Population (in millions). & 0.86 & 1.96 \\
\hline $\begin{array}{l}\text { County Percent } \\
\text { with Bachelor's }\end{array}$ & Percent of residents in county with Bachelor's degree (or higher). & 25.81 & 10.45 \\
\hline $\begin{array}{l}\text { Environmental } \\
\text { Org. Revenues } \\
\end{array}$ & $\begin{array}{l}\text { Revenues of environmental organizations in the state, normalized by } \\
\text { the population of the state. }\end{array}$ & 7.69 & 6.70 \\
\hline Federal Land & Percent of area of state that is federal land. & 8.26 & 14.21 \\
\hline Percent Kerry & Percent of voters in state who voted for Kerry in 2004. & 49.52 & 7.62 \\
\hline
\end{tabular}




\begin{tabular}{|l|l|r|c|}
\hline Variable Name & Description & Mean & $\begin{array}{l}\text { Std. } \\
\text { Dev. }\end{array}$ \\
\hline \multicolumn{1}{|c|}{ Other Factors } & 10.23 & 40.06 \\
\hline $\begin{array}{l}\text { School Growth } \\
\text { Rate }\end{array}$ & Percent increase in total students from 1990 to 2005. & 52.58 & 11.33 \\
\hline Percent Women & Percent of students that are women. & 0.21 & 0.41 \\
\hline Religious & Dummy equal to 1 if the institution has a religious affiliation. & 0.04 & 0.19 \\
\hline State System & Dummy equal to 1 if SEI grade for state system. & 0.23 & 0.42 \\
\hline South & Dummy equal to 1 if institution in southern state. & 0.15 & 0.36 \\
\hline New England & Dummy equal to 1 if institution in New England. & 0.08 & 0.28 \\
\hline Southwest & Dummy equal to 1 if institution in southwestern state. & 0.12 & 0.33 \\
\hline West & Dummy equal to if institution in western state. &
\end{tabular}


Table 3: Ordered Probit Results for SEI Sustainability Grade

\begin{tabular}{|c|c|c|c|c|c|c|}
\hline \multirow[b]{2}{*}{ Variable } & \multicolumn{2}{|c|}{ I: $\mathbf{N}=180$} & \multicolumn{2}{|c|}{ II: $N=180$} & \multicolumn{2}{|c|}{ III: $N=145$} \\
\hline & Coeff. & SE & Coeff. & SE & Coeff. & $\mathbf{S E}$ \\
\hline Regulatory Budget & 0.002 & 0.016 & -0.019 & 0.016 & -0.007 & 0.015 \\
\hline Enforcement Effort & -0.033 & 0.060 & -0.017 & 0.048 & -0.025 & 0.050 \\
\hline Inspection Rate & $-17.609 * *$ & 6.847 & $-20.807 * *$ & 6.962 & $-22.564 * *$ & 6.896 \\
\hline Total Students & $0.033^{* *}$ & 0.011 & $0.034 * *$ & 0.011 & $0.030 * *$ & 0.013 \\
\hline Tuition & $0.068 * *$ & 0.030 & $0.071 * *$ & 0.034 & 0.044 & 0.030 \\
\hline Percent on Financial Aid & $0.018 * *$ & 0.007 & $0.024 * *$ & 0.008 & $0.025 * *$ & 0.009 \\
\hline Public & $0.847 *$ & 0.460 & $1.141^{* *}$ & 0.470 & 0.587 & 0.410 \\
\hline Endowment & $0.985^{* *}$ & 0.350 & $0.990 * *$ & 0.349 & $1.160 * *$ & 0.354 \\
\hline High Research Activity & 0.288 & 0.325 & 0.137 & 0.320 & -0.241 & 0.362 \\
\hline Electricity Cost & -0.025 & 0.016 & -0.011 & 0.014 & -0.022 & 0.018 \\
\hline Acceptance Rate & 0.001 & 0.009 & -0.005 & 0.008 & -0.002 & 0.008 \\
\hline Top 50 National & 0.404 & 0.296 & 0.347 & 0.335 & $0.625 * *$ & 0.314 \\
\hline Top 50 Liberal Arts & 0.199 & 0.387 & 0.166 & 0.443 & 0.594 & 0.568 \\
\hline Percent On Campus & -0.538 & 0.733 & -0.514 & 0.669 & $-1.210 * *$ & 0.586 \\
\hline Environmental Major & 0.196 & 0.205 & 0.125 & 0.252 & 0.287 & 0.269 \\
\hline Percent Out of State & $1.204 * *$ & 0.564 & $1.192 * *$ & 0.517 & $0.995^{*}$ & 0.564 \\
\hline Percer & $6.299 * *$ & 2.495 & $5.069^{* *}$ & 2.519 & $8.325 * *$ & 2.327 \\
\hline Full-time Faculty & $0.037 * *$ & 0.016 & $0.040 * *$ & 0.017 & $0.042 * *$ & 0.016 \\
\hline Alumni Giving & $0.033 * *$ & 0.012 & $0.024 * *$ & 0.014 & 0.012 & 0.015 \\
\hline Size Relative to County & $0.039 * *$ & 0.013 & $0.032 * *$ & 0.010 & $0.031 * *$ & 0.007 \\
\hline County Population & $-0.111 * *$ & 0.062 & -0.050 & 0.059 & $-0.129^{*}$ & 0.066 \\
\hline $\begin{array}{l}\text { County Percent with } \\
\text { Bachelor's }\end{array}$ & $0.022 * *$ & 0.010 & $0.015^{*}$ & 0.009 & $0.020 * *$ & 0.008 \\
\hline $\begin{array}{l}\text { Environmental } \\
\text { Organization Revenues }\end{array}$ & -0.004 & 0.019 & 0.002 & 0.018 & 0.006 & 0.019 \\
\hline Federal Land & $0.033 * *$ & 0.012 & 0.020 & 0.013 & $0.034 * *$ & 0.013 \\
\hline Percent Kerry & 0.036 & 0.023 & 0.027 & 0.020 & $0.052 * *$ & 0.021 \\
\hline School Growth Rate & $0.295 * *$ & 0.124 & 0.267 & 0.196 & 0.086 & 0.118 \\
\hline Percent Women & $0.019 * *$ & 0.009 & $0.013 * *$ & 0.006 & -0.003 & 0.012 \\
\hline Religious & -0.294 & 0.258 & -0.269 & 0.274 & -0.142 & 0.369 \\
\hline State System & $1.482 * *$ & 0.348 & $1.243 * *$ & 0.327 & $1.217 * *$ & 0.315 \\
\hline South & -0.131 & 0.277 & -0.136 & 0.287 & 0.328 & 0.265 \\
\hline New England & $1.139 * *$ & 0.412 & $1.111 * *$ & 0.386 & $1.365 * *$ & 0.389 \\
\hline Southwest & -0.263 & 0.375 & -0.179 & 0.374 & -0.622 & 0.454 \\
\hline West & -0.624 & 0.660 & 0.235 & 0.673 & -0.517 & 0.656 \\
\hline Campus Survey & & & $1.476 * *$ & 0.229 & & \\
\hline Dining Survey & & & $0.620 * *$ & 0.179 & & \\
\hline
\end{tabular}

**Significant at the $95 \%$ level; *Significant at the $90 \%$ level. 
Table 4: Relative Effects of Changes in Significant Explanatory Variables

\begin{tabular}{|l|c|c|}
\hline Actual Grade & $\begin{array}{c}\text { Average } \\
\text { Grade }\end{array}$ & $\begin{array}{c}\text { Absolute } \\
\text { Change }\end{array}$ \\
\hline Baseline Prediction & 2.074 & \\
\hline Increase Inspection Rate One S.D. & 2.094 & \\
\hline Increase Total Students One S.D. & 1.960 & 0.134 \\
\hline Increase Tuition One S.D. & 2.275 & 0.181 \\
\hline Increase Percent on Financial Aid One S.D. & 2.285 & 0.191 \\
\hline All Private to All Public & 2.208 & 0.114 \\
\hline Increase Endowment One S.D. & & 0.391 \\
\hline Increase Out of State Percent One S.D. & 2.225 & 0.131 \\
\hline Increase International Percent One S.D. & 2.235 & 0.141 \\
\hline Increase Full-time Faculty One S.D. & 2.171 & 0.077 \\
\hline Increase Alumni Giving One S.D. & 2.196 & 0.102 \\
\hline Increase Size Relative to County One S.D. & 2.293 & 0.199 \\
\hline Increase County Population One S.D. & 2.253 & 0.159 \\
\hline Increase Percent with Bachelor's One S.D. & 1.975 & 0.119 \\
\hline Increase Federal Land One S.D. & 2.185 & 0.091 \\
\hline Increase School Growth Rate One S.D. & 2.291 & 0.197 \\
\hline Increase Percent Women One S.D. & 2.132 & 0.038 \\
\hline No State Systems to All State Systems & 2.176 & 0.083 \\
\hline
\end{tabular}


Table 5: Probit Results for Decision to Sign the PCC

\begin{tabular}{|l|c|c|}
\hline Variable & Coeff. & SE \\
\hline Regulatory Budget & 0.008 & 0.018 \\
\hline Enforcement Effort & -0.059 & 0.052 \\
\hline Inspection Rate & $15.152^{*}$ & 8.691 \\
\hline Total Students & -0.008 & 0.016 \\
\hline Tuition & 0.011 & 0.033 \\
\hline Percent on Financial Aid & 0.002 & 0.010 \\
\hline Public & 0.102 & 0.604 \\
\hline Endowment & -0.678 & 0.802 \\
\hline High Research Activity & 0.385 & 0.368 \\
\hline Electricity Cost & $0.029^{*}$ & 0.016 \\
\hline Acceptance Rate & 0.008 & 0.009 \\
\hline Top 50 National & -0.102 & 0.366 \\
\hline Top 50 Liberal Arts & $1.264^{* *}$ & 0.458 \\
\hline Percent On Campus & 0.322 & 0.772 \\
\hline Environmental Major & -0.044 & 0.306 \\
\hline Percent Out of State & -0.630 & 0.768 \\
\hline Percent International & -2.860 & 3.043 \\
\hline Full-time Faculty & 0.037 & 0.027 \\
\hline Alumni Giving & -0.001 & 0.018 \\
\hline Size Relative to County & 0.054 & 0.104 \\
\hline County Population & 0.022 & 0.082 \\
\hline County Percent with Bachelor's & -0.006 & 0.011 \\
\hline Environmental Organization Revenues & 0.025 & 0.019 \\
\hline Federal Land & $0.043 * *$ & 0.018 \\
\hline Percent Kerry & 0.010 & 0.025 \\
\hline School Growth Rate & 0.006 & 0.261 \\
\hline Percent Women & 0.005 & 0.006 \\
\hline Religious & 0.260 & 0.410 \\
\hline State System & 1.014 & 0.647 \\
\hline South & 0.048 & 0.303 \\
\hline New England & -0.414 & 0.287 \\
\hline Southwest & 0.189 & 0.416 \\
\hline West & -1.538 & 0.942 \\
\hline Constant & $-6.285 * *$ & 2.860 \\
\hline Signfint at & & \\
\hline
\end{tabular}

**Significant at the $95 \%$ level; *Significant at the $90 \%$ level. 
Figure 1: Overall Sustainability Grade Distribution

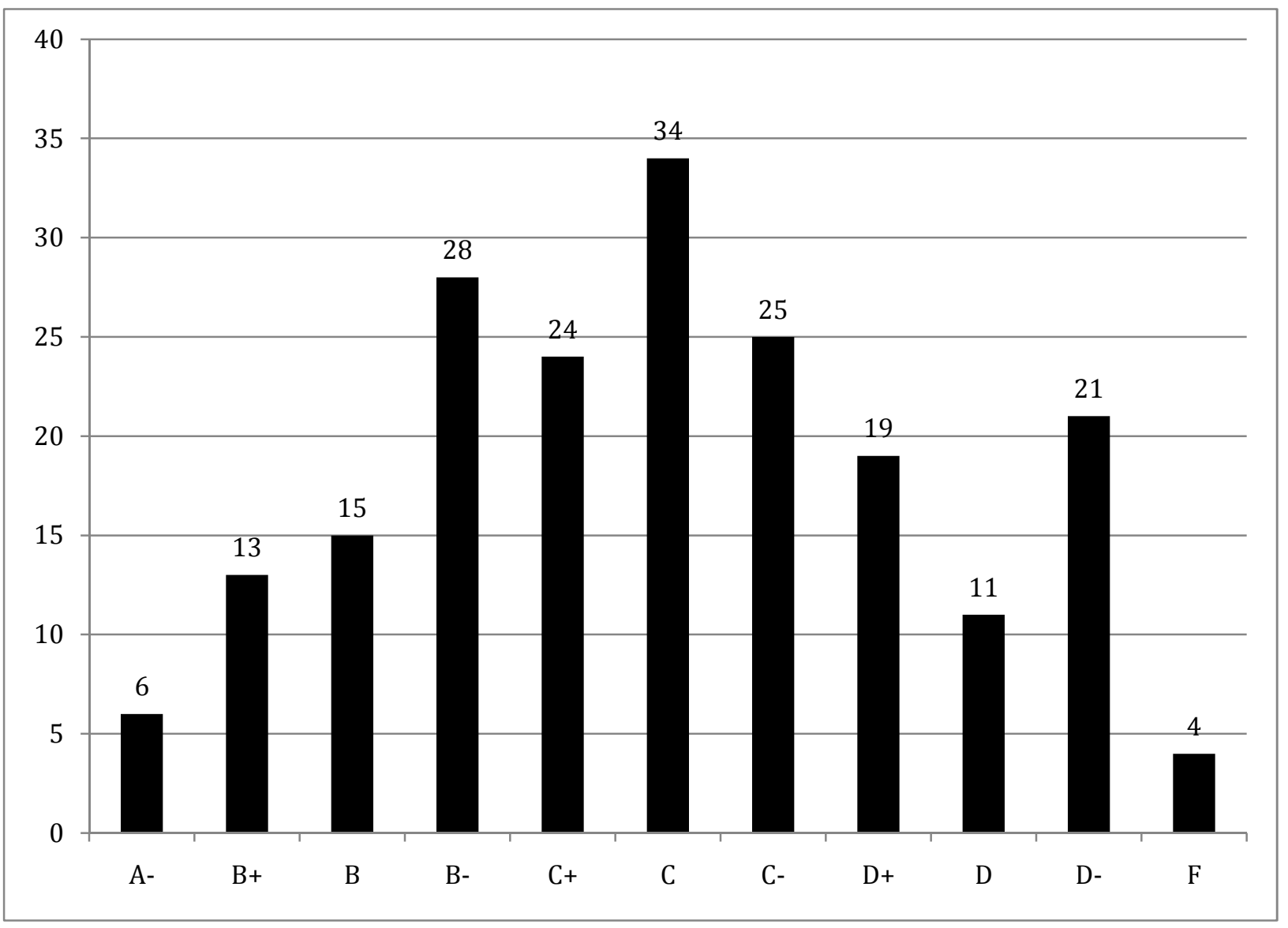


Figure 2: Actual vs. Predicted Grades

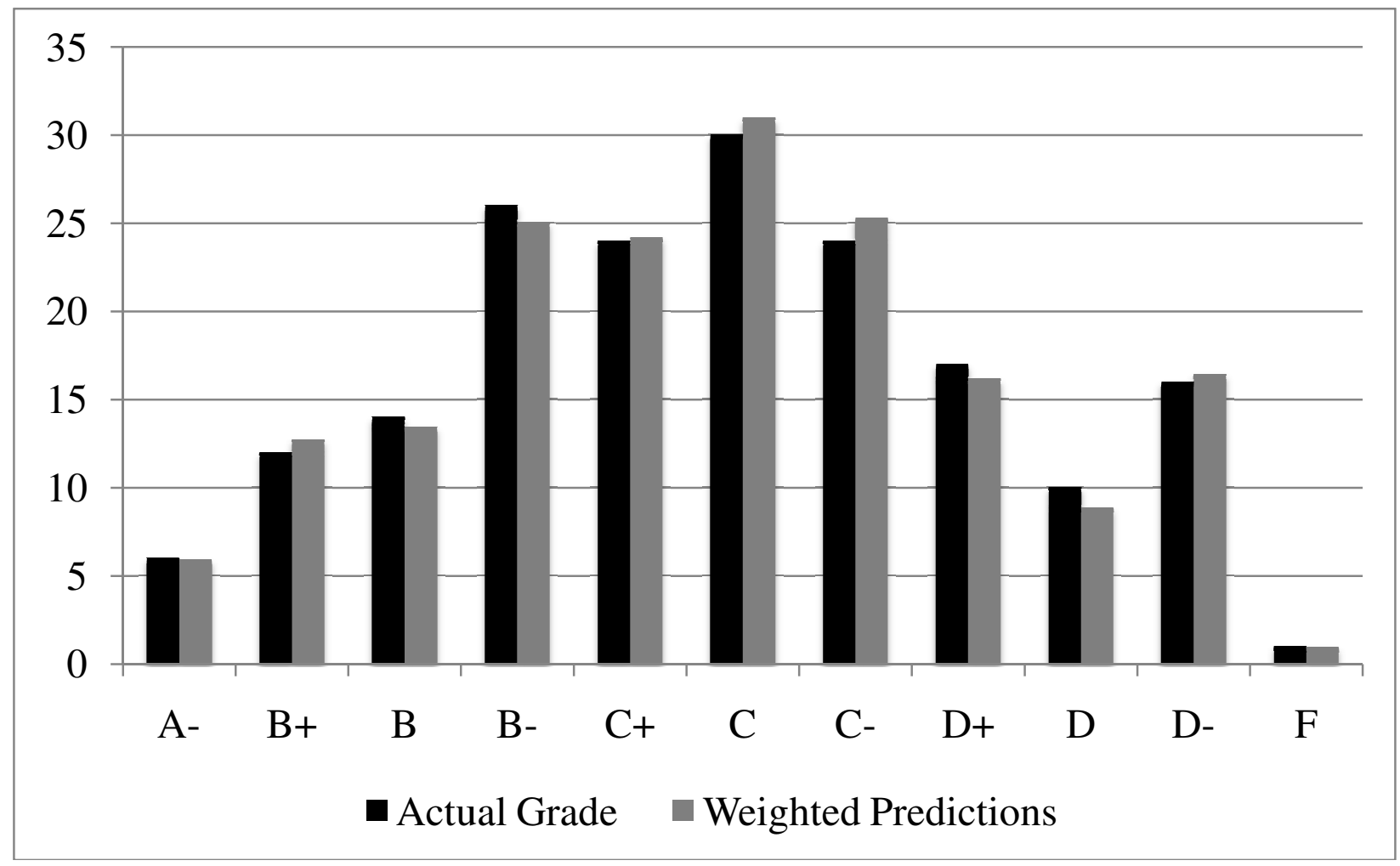


Figure 3: Effect of Increase in Selected Explanatory Variables

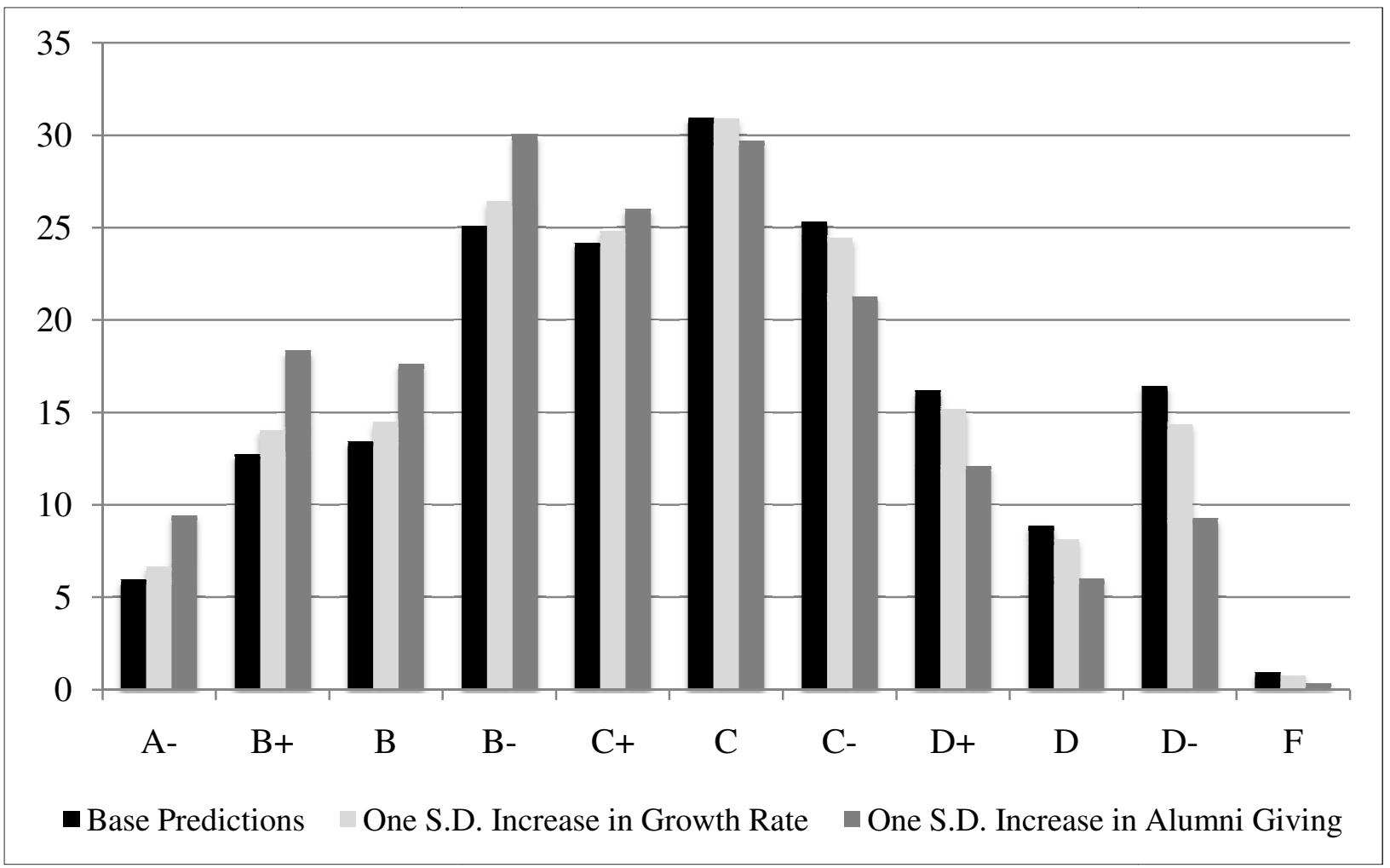


Figure 4: Distribution of PCC Signatories

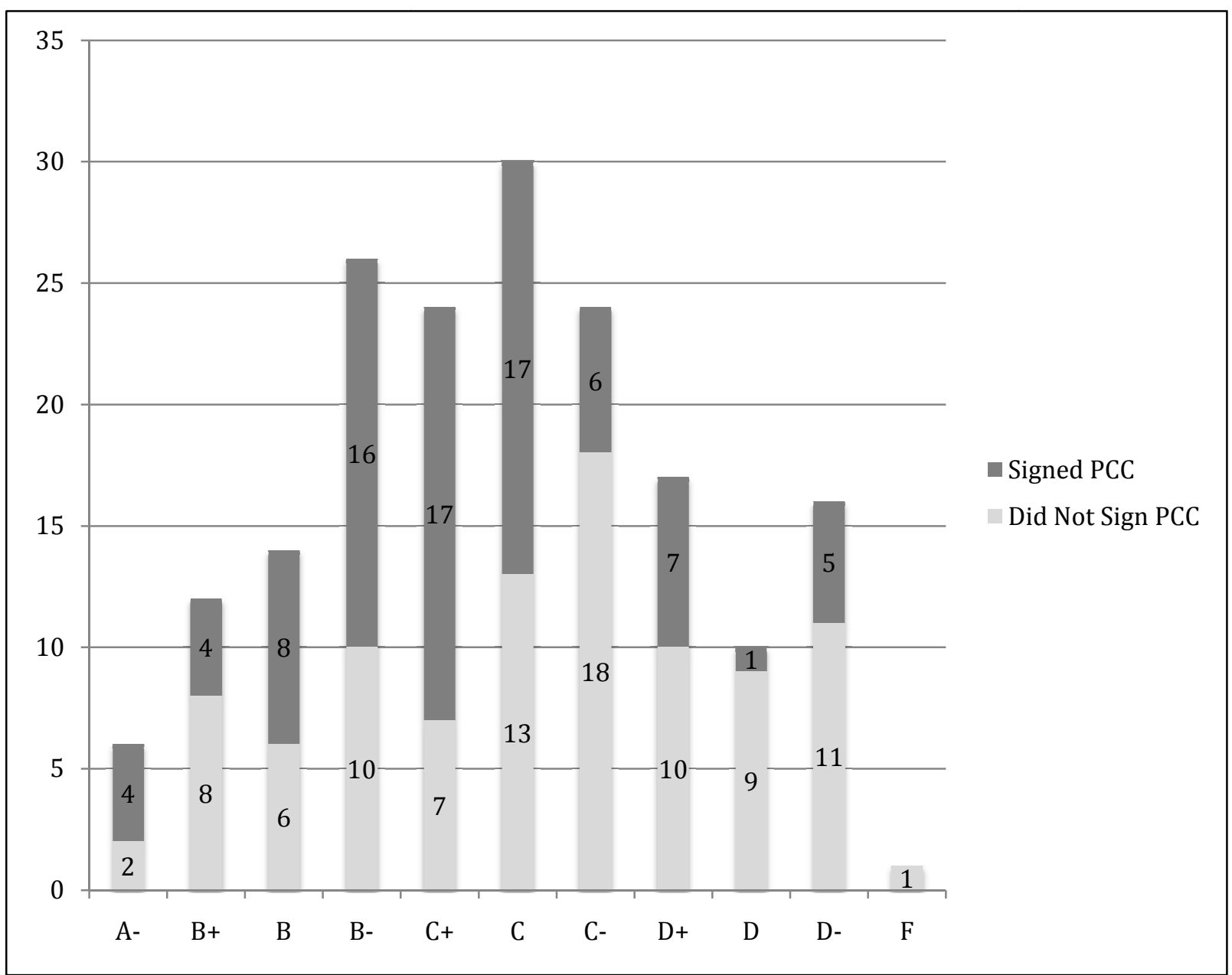

Source: http://www.presidentsclimatecommitment.org/html/signatories.php, accessed on January 19, 2009. 